\title{
MESIN PEMBUAT BAHAN BAKU PATI DARI UBI KAYU DENGAN KAPASITAS 30 KG/JAM
}

\author{
Jusnita \\ Dosen Fakultas Teknik Jurusan Teknik Otomotif \\ Universita Muhamadiyah Riau, Email: jusnita_ita@yahoo.co.id
}

\begin{abstract}
ABSTRAK
Pemanfaatan Ubi Kayu untuk bahan baku makanan dapat dilakukan dengan melakukan proses pengolahan dengan menggunakan mesin berteknologi tepat guna, untuk memperoleh hasil yang diinginkan. Mesin pembuat bahan baku pati dari Ubi Kayu adalah mesin yang direncanakan khusus untuk mengeluarkan pati yang terkandung pada Ubi Kayu. Mesin ini bekerja pada metode pemarutan dan pengempaan hingga menghasilkan pati. Perencanaan mesin penghasil pati Ubi Kayu bertujuan untuk mengetahui kapasitas produksi dengan efisiensi yang baik dan lebih berkwalitas. Ubi Kayu yang telah dipisahkan dari kulitnya direndam dalam larutan natrium bisulfit, diparut dalam rotor pemarut, Hasil pemarutan kemudian diperas dalam silinder kempa sehingga diperoleh cairan yang mengandung pati basah. Mesin ini direncanakan juga dapat dilakukan proses pembuatan bahan tepung. Metode perencanaan yang digunakan berdasarkan studi literatur dengan perbandingan secara teoritis. Perhitungan teoritis pada komponen-komponen utama dan pendukung dalam perencanaaan yang dilakukan pemilihan bahan dan penentuan komponen perancangan. Berdasarkan metode perancangan didapat hasil komponen dan kapasitas $30 \mathrm{~kg} / \mathrm{jam}$. Mesin ini direncanakan hanya untuk mendapatkan tepung basah dari cairan pati Ubi Kayu. Untuk memperoleh tepung maka dibutuhkan proses lebih lanjut.
\end{abstract}

Kata kunci: Mesin pembuat bahan baku, pemarutan, pengempaan, pati basah, pengendapan tepung

\section{PENDAHULUAN}

Seiringan dengan perkembangan Teknologi mesin pertanian yang dicapai saat ini khususnya dalam bidang teknologi tepat guna, maka dibutuhkan suatu peningkatan kualitas bidang sarana dan prasarana penunjang dalam meningkatkan hasil produksi dengan peralatan tepat dan efisien, sehingga baik produksi yang dicapai nantinya dapat lebih berkwalitas.

Untuk memenuhi sarana dan prasarana dalam hasil produksi banyak hal-hal yang harus diperhitungkan, diantaranya lebih efisien dan keefektifan alat yang dirancang. Hal inilah yang menjadi faktor utama penulis untuk membuat perencanaan suatu alat, yang dapat untuk menghasilkan produksi yang lebih baik.

Ubi kayu, sebagai salah satu komoditi atau jenis tanaman pangan yang telah bermasyarakat dan digunakan banyak konsumen, bahan makanan yang bergizi dengan mengambil patinya untuk kemudian dijadikan tepung. Pati Ubi Kayu yang merupakan bahan baku tepung dapat diambil dengan urutan proses seperti pengambilan, pembersihan, pemarutan, pengempaan dan pengendapan. Dari prosesproses ini dapat diketahui bahwa apabila pekerjaan tersebut dikerjakan dengan manual atau tanpa mesin, membutuhkan waktu yang lama, Sehingga perlu dikembangkan dan ditingkatkan produksinya. Usaha untuk meningkatkan produksi ini adalah apabila petani memiliki ketrampilan dan sekaligus menggunakan teknologi yang tepat guna.

Dengan alasan tersebut diatas, penulis merencanakan mesin yang berfungsi untuk memperoleh pati ubi kayu, dengan cara pemarutan dan pengempaan untuk mendapatkan tepung maka pati yang ditetapkan tersebut diendapkan.

Penulisan ini bertujuan untuk merancang ulang teknologi tepat guna yang masih sangat minim yang ada di Sumatera Utara, maka perencanaan mesin ini selanjutnya akan dijadikan sebagai tugas sarjana dengan judul perencanaan mesin pembuat bahan baku pati ubi kayu. yang 
dapat digunakan untuk keperluan pengusaha kecil (Home Industry).

\section{METODOLOGI PENELITIAN}

Tujuan penelitian ini untuk merencanakan Mesin teknologi tepat guna. Perencanaan mesin pengolahan pati bahan baku ubi kayu. Sehubungan dengan perencanaan ini, penulis juga memperhatikan tujuan dasar perencanaan agar dapat menjelaskan prinsip kerja mesin, menghitung dimensi komponen - komponen utama mesin serta membuat gambar mesin dan untuk mengetahui efisiensi dan kapasitas produksi.

Singkong atau ubi kayu berasal dari Brazil, Amerika Selatan, yang menyebar ke Asia pada awal abad ke-17 dibawa oleh pedagang Spanyol dari Mexico ke Philipina. Kemudian menyebar ke Asia Tenggara, termasuk Indonesia. Ubi kayu merupakan makanan pokok di beberapa negara Afrika. Di samping sebagai bahan makanan, ubi kayu juga dapat digunakan sebagai bahan baku industri dan pakan ternak. Ubinya mengandung air sekitar 60\%, pati (25-35\%), protein, mineral, serat, kalsium, dan fosfat. Ubi kayu merupakan sumber energi yang lebih tinggi dibanding padi, jagung, ubi jalar.

Ubi kayu mengandung HCN(asam Sianida) yang terdapat di dalam umbi, dan daunnya. Untuk keperluan makanan dan pakan ternak digunakan ubi kayu yang kadar HCN-nya rendah (kurang dari $50 \mathrm{mg} / \mathrm{Kg}$ umbi). Sedangkan untuk bahan industri digunakan ubi kayu yang berkadar $\mathrm{HCN}$ tinggi.

Keanekaragaman sifat yang terdapat di dalam plasma nutfah tanaman sangat besar perannya dalam pemuliaan tanaman, seperti keragaman kandungan mutu gizi bermanfaat untuk perbaikan tanaman bermutu gizi tinggi. Analisis mutu gizi dilakukan di Laboratorium Biokimia dan Enzimatik Balitbio tahun 2001 terhadap kandungan amilosa pada kandung-an HCN pada ubi kayu berkisar antara $8,3-150 \mathrm{~mm} / \mathrm{Kg}$ umbi, dan pada daun ubi kayu antara 59,4-532,6 $\mathrm{mm} / \mathrm{Kg}$ umbi.

\section{Kandungan Kimia:}

Ubi kayu mempunyai komposisi kandungan kimia (per 100 gram ) antara lain:

- Kalori 146 kal

- Protein 1,2 gram

- Lemak 0,3 gram

- Hidrat arang 34,7 gram

- Kalsium $33 \mathrm{mg}$

- Fosfor $40 \mathrm{mg}$

- Zat besi 0,7 mg.

Buah ubi kayu mengandung ( per 100 gram ):

- Vitamin B1 0,06 mg

- Vitamin C $30 \mathrm{mg}$

- dan $75 \%$ bagian buah dapat dimakan.

Daun ubi kayu mengandung (per 100 gram ):

- Vitamin A 11000 SI

- Vitamin C $275 \mathrm{mg}$

- Vitamin B1 0,12 mg

- Kalsium 165 mg

- Kalori $73 \mathrm{kal}$

- Fosfor $54 \mathrm{mg}$

- Protein 6,8 gram

- Lemak 1,2 gram

- Hidrat arang 13 gram

- Zat besi $2 \mathrm{mg}$

- dan $87 \%$ bagian daun dapat dimakan.

Kulit batang ubi kayu mengandung tanin, enzim peroksidase, glikosida dan kalsium oksala. 


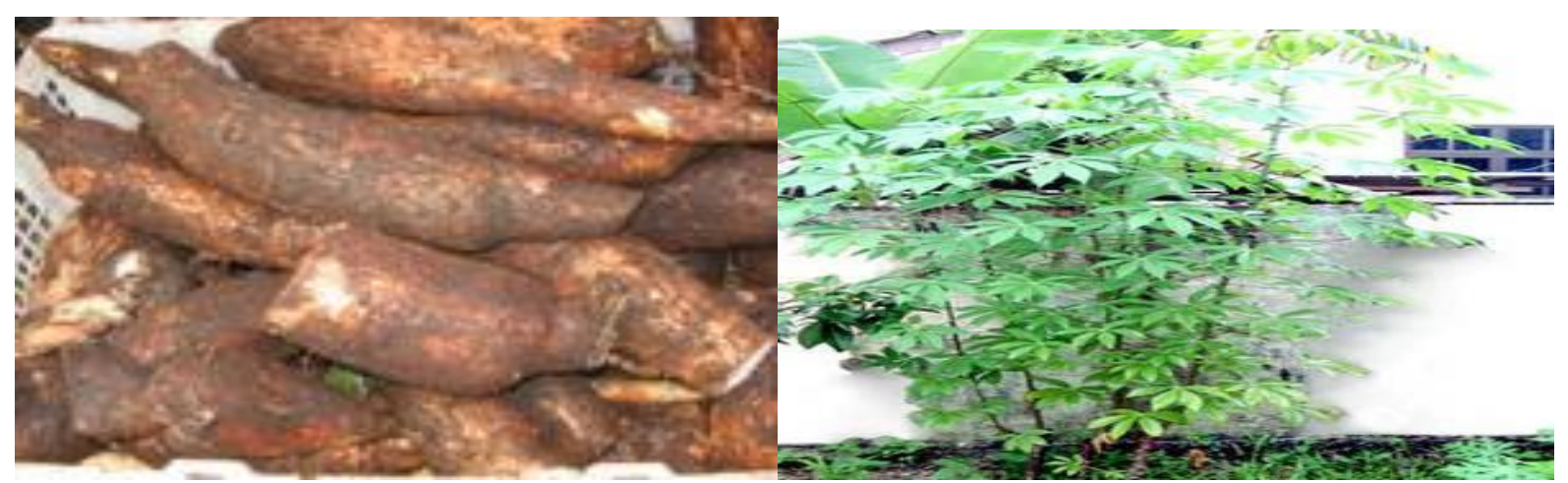

Gambar. 1\&2. Tanaman Dan Buah Ubi Kayu

Varietas bibit unggul ubi kayu yang mempunyai kualitas yang baik, yaitu Adira-4, Malang-1, dan Darul Hidayah. Sedangakan varietas unggul Malang-4 dan Malang-6, tahan hama tungau merah, mempunyai hasil yang tinggi yaitu $35-40$ ton per hektar dengan kadar tepung/pati yang tinggi dan umur panen 9 bulan. Dua varietas unggul lainnya yaitu varietas UJ-3 dan UJ-5 mempunyai hasil cukup tinggi tahan Cassava Backterial Blight (CBB) dan dapat dipanen pada umur $8-10$ bulan.

Disamping digunakan untuk tapioka, ubikayu dapat diolah menjadi produk antara berupa tepung ubikayu dan serbuk ubikayu. Tepung ubikayu dibuat dari ubikayu irisan (chips/sawut) ubikayu segar yang dipres selanjutnya dikeringkan dan digiling. Kegunaan tepung ubikayu dapat untuk subtitusi terigu dalam pembuatan kue kering, kue basah, mie, atau roti, dengan tingkat subtitusi menjadi $20-$ 100 persen. Dalam rangka meningkatkan nilai tambah tepung ubikayu dapat dilakukan penambahan tepung kacang-kacangan menjadi tepung komposit.

Cara membuat serbuk ubikayu yaitu dari parutan ubikayu segar selanjutnya dipres, dikeringkan, dihancurkan lalu diayak, dan kemudian disangrai. Serbuk ubikayu juga dapat dibuat lauk pauk buatan seperti Farofa dan minuman instan. Sedangkan farofa telur dibuat dengan konsentrasi serbuk ubikayu sekitar 24 persen dan untuk farofa jagung konsentrasinya mencapai 17 persen.

Sebelum diolah lebih lanjut, ubi kayu diproses terlebih dahulu agar tidak mudah rusak dan bewarna kebiru-biruan, karena ubi kayu mudah mengalami perubahan warna bila kontak langsung dengan udara.

Dalam mencegah hal ini ubi kayu perlu direndam dalam larutan $\mathrm{Na}$ bisulfit, setelah ubi kayu dipisahkan dari kulitnya lalu di rendam dalam larutan $1 \% \mathrm{Na}$ Bisulfit selama dua sampai tiga menit, setelah itu dilakukan proses selanjutnya. Untuk menghasilkan pati dari ubi kayu tersebut maka harus dilakukan dalam beberapa proses seperti diagram dibawah:

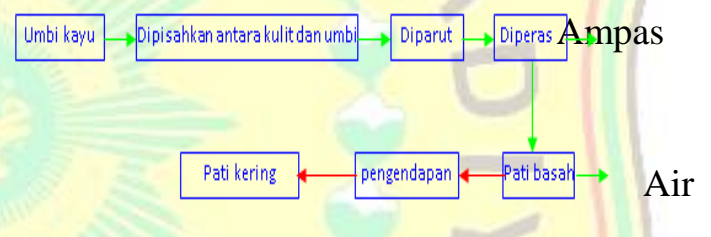

Dasar Perencanaan Dan Pemilihan Komponen-Komponen Mesin

Sebagai penggerak mula, motor listrik mempunyai beberapa keuntungan sebagai berikut:

1. Penggunaannya memberikan ongkos yang murah jika ada sumber dari PLN.

2. Pengoprasianya mudah.

3. Ringan dan hampir tidak menimbulkan getaran.

4. Perawatan dan pengaturanya mudah.

Pemilihan suatu motor listrik dipilih berdasarkan atas daya dan putaran yang harus dipenuhinya. Daya berhubungan dengan kemampuan untuk melakukan proses sedangakan putaran berkaitan dengan kapasitas mesin yang akan digerakkannya.

Daya motor dapat dihitung berdasarkan persamaan:

$\mathrm{P}=$ m.g.v

Dimana; 


$$
\begin{aligned}
& \mathrm{P}=\operatorname{daya}(\mathrm{W}) \\
& \mathrm{m}=\operatorname{massa}(\mathrm{kg}) \\
& \mathrm{g}=\operatorname{gravitasi}\left(9,81 \mathrm{~m} / \mathrm{s}^{2}\right) \\
& \mathrm{v}=\operatorname{kecepatan}
\end{aligned}
$$

Motor listrik yang umumnya digunakan adalah motor listrik induksi. Pada motor ini terjadi slip antara stator dan rotornya sehingga putaran sikronya lebih besar sedikit dengan putaran motornya. Besarnya slip yang terjadi berkisar antara $5 \%-10 \%$. Putaran keluaran suatu motor induksi dihitung dengan persamaan

$$
\begin{aligned}
& \mathrm{N}=\mathrm{n}_{\mathrm{o}}\left(1-\frac{s}{100}\right) \\
& \mathrm{N}=\text { putaran keluaran motor }(\mathrm{rpm}) \\
& \mathrm{n}_{\mathrm{o}}=\text { putaran sinkron }(\mathrm{rpm}) \\
& \mathrm{S}=\text { slip }
\end{aligned}
$$

\section{Sabuk dan Pulli -V}

Sabuk adalah elemen transmisi yang berfungsi untuk mereduksi putaran. Karena elemen ini elastis, sabuk mempunyai peranan penting dalam menyerap beban kejut dan meredam pengaruh getaran. Sabuk juga berfungsi untuk meneruskan daya atau putaran antara dua buah poros yang tidak memungkinkan transmisi langsung dengan roda gigi. Sabuk V terbuat dari karet dengan penampang trapesium

Hal - hal yang perlu ditentukan pada perancangan ini adalah tipe sabuk, perbandingan putaran, diameter pulli, panjang sabuk, jarak sumbu poros, dan jumlah sabuk yang diperlukan untuk memindahkan daya.

Jarak sumbu poros harus sebesar 1,5 - 2 kali diameter besar.

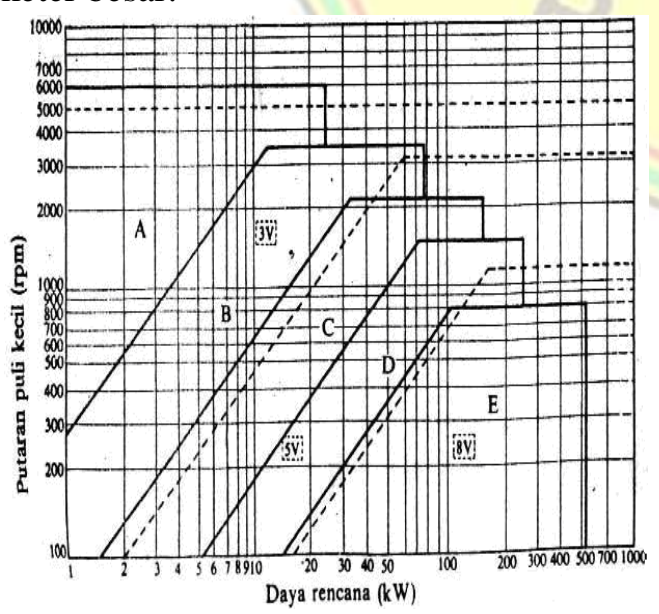

\section{Diagram Pemilihan Sabuk}

Diameter pulli kecil yang diizinkan disesuaikan dengan tipe sabukya.

Diameter Minimum Pulli Yang Diizinkan Dan Dianjurkan (mm)

\begin{tabular}{|l|c|c|c|c|c|}
\hline \multicolumn{1}{|c|}{ Penampang } & A & B & C & D & E \\
\hline Diameter minimum & & & & & \\
yang diizinkan \\
$\begin{array}{l}\text { Diameter minimum } \\
\text { yang diizinkan }\end{array}$ & 65 & 115 & 175 & 300 & 450 \\
\hline
\end{tabular}

Umumnya sabuk V dipasang secara terbuka.

Perhatikan gambar berikut ini:

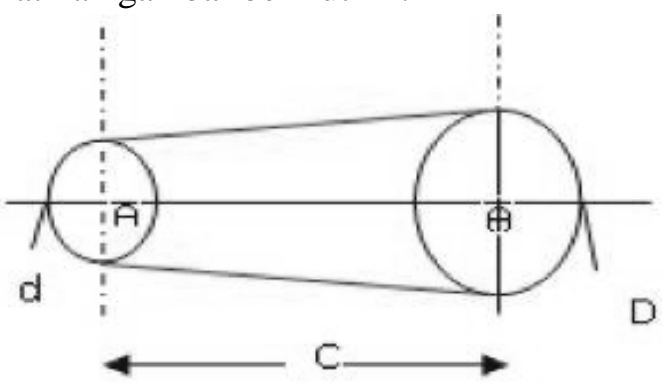

$$
\begin{aligned}
& \text { Pemasangan sabuk }-\mathbf{V} \text { terbuka } \\
& \mathrm{d}=\text { diameter pulli kecil }(\mathrm{mm}) \\
& \mathrm{D}=\text { diameter pulli besar }(\mathrm{mm}) \\
& \mathrm{n}_{1}=\text { putaran pulli besar }(\mathrm{mm}) \\
& \mathrm{n}_{2}=\text { putaran pulli besar }(\mathrm{mm}) \\
& \mathrm{C}=\text { jarak sumbu poros }(\mathrm{mm}) \\
& \theta=\text { sudut kontak }\left({ }^{0}\right) \text { atau }(\mathrm{rad})
\end{aligned}
$$

Poros

Poros adalah suatu elemen mesin yang dapat berfungsi sebagai pendukung elemen mesin lainya dan sebagai pemindah daya dan putaran., hal-hal yang harus perlu diperhatikan dalam perencanaan sebuah poros adalah:

\section{Kekuatan Poros}

Poros transmisi dapat mengalami beban puntir atau lentur atau gabungan antara puntir dan lentur.

\section{Kekakuan Poros}

Meskipun sebuah poros mempunyai kekuatan yang cukup tetapi jika lenturan atau defleksi terlalu besar akan mengakibatkan ketidaktelitian atau getaran atau suara, karena itu kekakuan juga harus diperhatikan dan disesuaikan dengan macam mesin yang akan dilayani poros tersebut.

\section{Putaran Kritis}

Bila putaran mesin dinaikan maka pada suatu harga putaran tertentu dapat terjadi getaran yang luar biasa besarnya. Putaran ini disebut putaran kritis. 
4. Bahan Poros

Poros untuk mesin umum biasanya dibuat dari baja batang yang ditarik dingin dan difinis, baja karbon konstruksi mesin (disebut bahan S-C) yang dihasilkan dari ingot yang di "kill" (baja yang dideoksidasikan dengan ferrosilicon dan dicor

\section{Cara Kerja Mesin}

Ubi kayu yang telah direndam dan dicuci dengan air hingga bersih, dimasukaan kedalam corong masukan. Ubi kayu ini kemudian akan diparut oleh rotor pemarut sehingga akan tercacah menjadi halus. Hasil cacahan ini selanjutnya masuk kedalaman silinder kempa melalui salauran yang telah dibuat. Didalam sislinder kempa ini, ubi kayu akan dibawa oleh ulir kempa keujung silinder dan ujung silinder aliran massa ubi kayu akan ditahan oleh kunus penahan. Setelah melewati poses-proses tersebut ubi kayu akan diperas dan cairan hasil perasanya akan keluar dari bagian bawa silinder, sementara hasil perasannya (ampas) akan keluar dan disaring oleh saringan dibawah silinder. Saringan ini akan menyaring ampas kering yang terikut bersama-sama dengan cairan hingga diperoleh caiaran yang benar-benar bersih. Cairan ini ditampung dalam wadah yang telah dipersiapkan.

Cairan yang telah diperoleh ini merupakan bahan baku yang nantinya akan diendapkan untuk diperoleh tepung basah. Namun mesin ini didesain hanya untuk mendapatkan bahan baku ini karena untuk memperoleh tepung maka dibutuhkan proses lebih lanjut dinama dapat dilihat pada gambar dibawah ini.

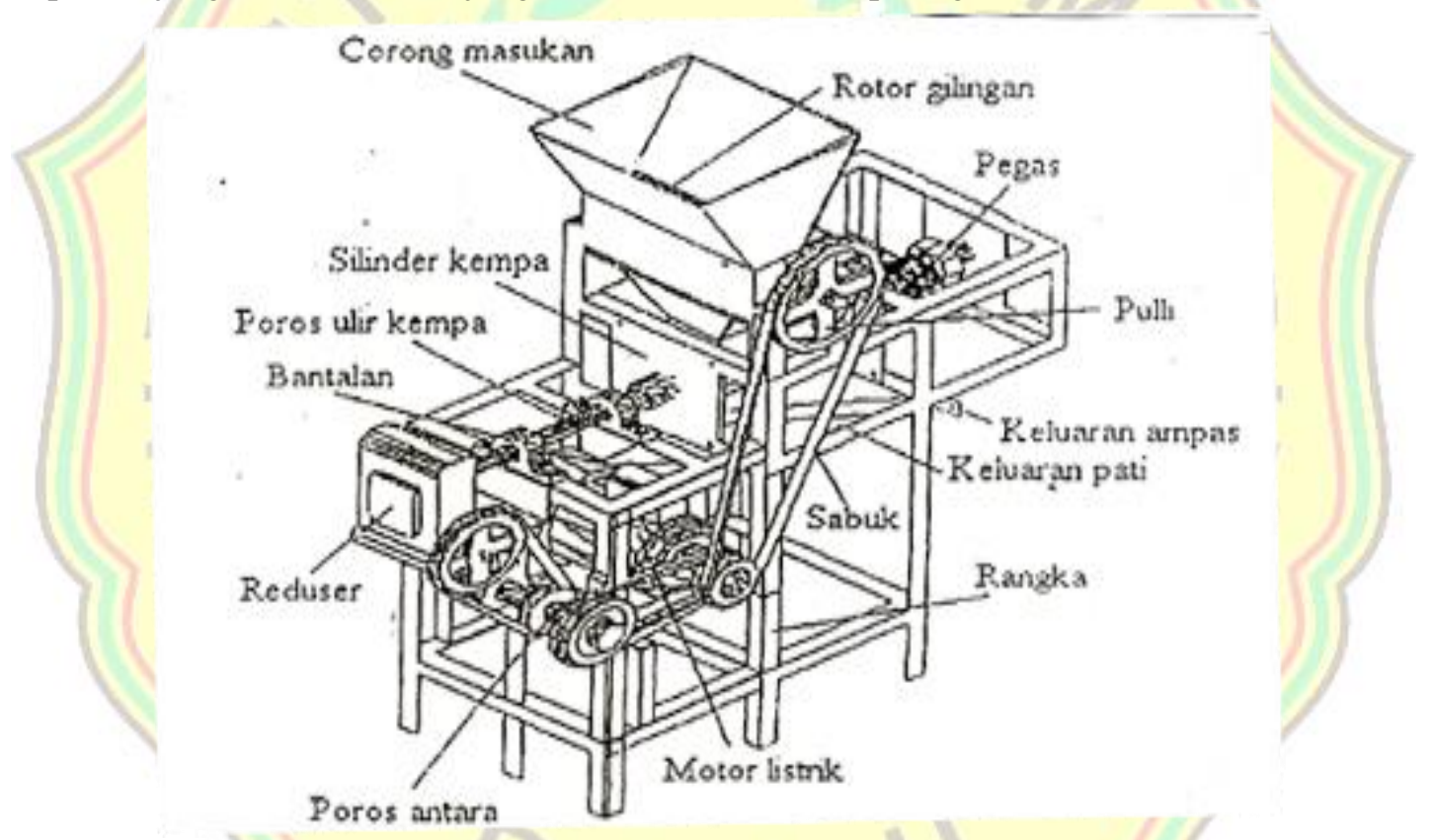

Gambar 3.Mesin Pembuat Bahan Baku Tepung Ubi kayu

\section{HASIL DAN PEMBAHASAN}

\section{Perencanaan Dan Pemilihan Bagian}

\section{Utama Mesin}

Penggerak yang digunakan pada mesin ini adalah motor listrik. Motor listrik dipilih berdasarkan daya dan putaran yang harus dipenuhinya. Putaran motor berhubungan kapasitas mesin. Sedangkan dayanya berhubungan dengan kemampuannya untuk memarut dan mengempa.

Putaran Motor Pemarut
Pada rotor pemarut terdapat kawat- kawat pemarut apabila ubi kayu masuk kedalamnya maka akan terjadi proses pemarutan. Diasumsikan bahwah jumlah kawat yang mengenai ubi kayu adalah sejumlah 1/4 lingkaran rotor. Dimana diameter rotor pemarut ditentukan $120 \mathrm{~mm}$ dan jarak antara kawat $10 \mathrm{~mm}$ jumlah kawat parut didalam $1 / 4$ lingkaran rotor adalah Panjang $1 / 4$ lingkaran rotor

$\mathrm{Z}=$ 


$$
=\frac{\frac{\pi}{4} D}{10}=\frac{\frac{\pi}{4} \times 120}{10}=9,43 \mathrm{~mm}=10 \mathrm{~mm}
$$

Maka jumlah kawat parut dalam 1/4 lingkaran rotor adalah 10 Buah

Panjang rotor ditentukan $250 \mathrm{~mm}$, maka terdapat 25 buah kawat tiap baris. Untuk $1 / 4$ lingkaran rotor maka terdapat $25 \times 10=250$ buah kawat. Maka jumlah kawat keseluruhan adalah $4 \times 250=$ 1000 buah kawat pemarut.

Kawat pemarut terbuat dari kawat diameter 1,5 mm, panjang kawat diatas rotor $5 \mathrm{~mm}$, maka volume ubi kayu yang terparut oleh kawat adalah:

$\mathrm{V} 1=8,84 \mathrm{~m}=8,84 \times 10-9 \mathrm{~mm}^{3}$

Maka untuk satu putaran volume ubi kayu yang terparut adalah:

$\mathrm{V} 1$ put $=\mathrm{V} 1 \mathrm{x}$ ztot $=8,84 \times 10-9 \mathrm{~mm}^{3}$

Massa ubi kayu adalah $127 \mathrm{Kg} / \mathrm{m}^{3}$. Maka massa ubi kayu yang terparut dalam satu putaran adalah: $\mathrm{m}=\rho \times \mathrm{V}_{1}$ put

$$
\begin{aligned}
& =127 \mathrm{Kg} / \mathrm{m}^{3} \times 8,84 \times 10^{-6} \mathrm{~m}^{3} \\
& =1122,172 \times 10^{-6} \mathrm{Kg} / \mathrm{m}^{3}
\end{aligned}
$$

Dengan kapasitas mesin yang direncanakan adalah $30 \mathrm{~kg} / \mathrm{jam}$ atau $0,5 \mathrm{~kg} /$ menit. Untuk dapat memenuhi kapasitas ini maka rotor pemarut adalah:

$$
\begin{aligned}
\mathrm{n} & =\frac{\text { massa/menit }}{\text { massa/ putaran }} \\
& =\frac{0,5}{1122,172 \times 10^{-6}} \\
& =446 \mathrm{rpm} .
\end{aligned}
$$

\section{Putaran Ulir Kempa}

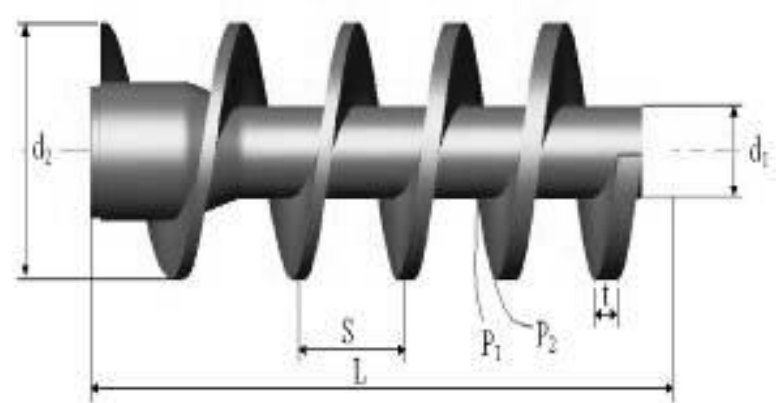

Gambar Poros Ulir Kempa
Untuk mendapatkan putaran yang sesuai dengan kondisi mesin, maka putaran ini akan direduksi oleh kombinasi pulli dan worm gear speed reduce

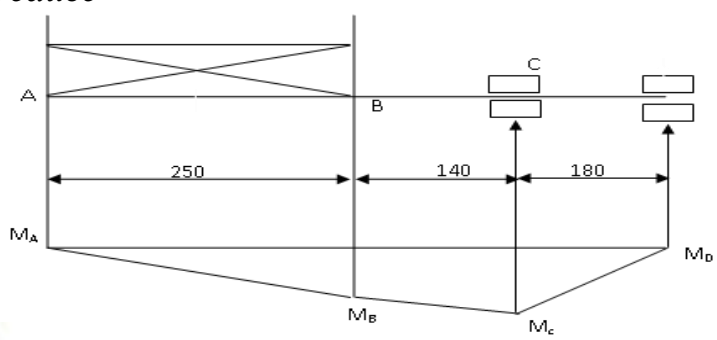

Gambar Diagram Momen Poros Ulir Kempa $\Sigma \mathrm{M}_{\mathrm{C}} \quad=0 ;-\mathrm{R}_{\mathrm{D}} \times 180+$ Fsp $\times 250$

$$
-R_{D}=\frac{210 \times 250}{180}=291,67 \mathrm{~N}
$$

$\Sigma \mathrm{M}_{\mathrm{D}}=0 ; \mathrm{R}_{\mathrm{C}} \times 180+$ Fsp $\mathrm{x} 445$

$$
-\mathrm{R}_{\mathrm{C}}=\frac{210 \times 445}{180}=519,17 \mathrm{~N}
$$

Harga - Harga Momen Lentur

$\mathrm{M}_{\mathrm{B}}=-\mathrm{F}_{\mathrm{SP}} \mathrm{x} 125$

$=210 \times 125$

$=-26250 \mathrm{Nmm}$.

$\mathrm{M}_{\mathrm{C}}=-\mathrm{F}_{\mathrm{SP}} \times 265$

$=210 \times 265$

$=-55650 \mathrm{Nmm}$.

Momen maksimum terjadi pada titik C.

Torsi ekivalen dengan mengambil harga

$\mathrm{K}_{\mathrm{m}}=1,6$ dan $\mathrm{K}_{\mathrm{t}}=1,1$

$\mathrm{Te}=\sqrt{\left\{\left(\mathrm{K}_{\mathrm{m}} \mathrm{M}\right)+\frac{\alpha \mathrm{Fd}}{8}\right\}^{2}+\left(\mathrm{K}_{1} \mathrm{~T}\right)^{2}}$

$\mathrm{Te}=\frac{\pi}{16} \times \mathrm{d}^{3} \times \tau$

$=\frac{\pi}{16} 35^{3} \mathrm{x} \tau \rightarrow \tau=36,233 \mathrm{~N} / \mathrm{mm}$.

Bahan poros yang digunakan adalah sama dengan poros pemarut yaitu, S $30 \mathrm{C}, \tau b=58\left(\mathrm{Kg} \cdot \mathrm{mm}^{2}\right) \mathrm{x}$ $9,80665=568,78 \mathrm{~N} / \mathrm{mm}^{2}$, maka tegangan izin bengkok dan tegangan geser adalah $\sigma_{1}: 102,38$ $\mathrm{N} / \mathrm{mm}^{2}$, dan $\tau=51,19 \mathrm{~N} / \mathrm{mm}$. Karena tegangan yang terjadi lebih kecil dari harga yang diizinkan maka diameter poros yang sebelumnya direncanakan sudah sesuai.

\section{Pemilihan Kopling}

Kopling dipakai untuk menyambung poros output reduser dengan poros ulir kempa. Dengan 
pertimbangan bahwa yang akan terjadi sedikit tidak sesumbuan antara poros reduser dengan poros ulir kempa. Maka digunakan kopling rantai fleksibel yang mengizinkan sedikit ketidak sesumbuannya poros yang disambunganya. Ukuran-ukuran utama kopling rantai sebagai berikut:

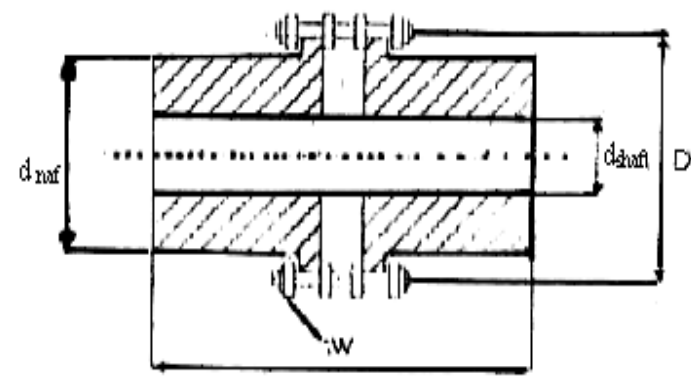

\section{Gambar Ukuran-Ukuran Utama \\ Pemilihan Bantalan}

Pada mesin ini digunakan enam buah bantalan yang terdiri empat buah bantalan bola dan dua bantalan kerucut. Bantalan bola digunakan untuk mendukung poros rotor pemarut dan poros antara. Sedangkan bantalan kerucut untuk poros ulir kempa.

Bantalan Rotor Pemarut

Sesuai dengan catalog bantalan pada table sularso direncanakan diameter dalam bantalan (d) $=25 \mathrm{~mm}$ yang mempunyai harga kapasitas nominal dinamis spesifik

$(\mathrm{C})=790(\mathrm{Kg}) \times 9,80665(\mathrm{~N})=7747,254 \mathrm{~N}$, dan harga kapasitas nominal statis spesifik $(\mathrm{Co})=$ $530(\mathrm{Kg}) \times 9,80665(\mathrm{~N})=5197,525 \mathrm{~N}$

Resultan reaksi -reaksi (lihat perencanaan poros) pada masing-masing bantalan dihitung sebagia berikut:

$\mathrm{R}_{\mathrm{A}}=\sqrt{\mathrm{R}_{\mathrm{AH}}{ }^{2}+\mathrm{R}_{\mathrm{AV}}{ }^{2}}$

$\sqrt{(41,68915)^{2}+(12,591545)^{2}}=43,55 \mathrm{~N}$.

$\mathrm{R}_{\mathrm{D}}=\sqrt{\mathrm{R}_{\mathrm{DH}}{ }^{2}+\mathrm{R}_{\mathrm{DV}}{ }^{2}}$

$=\sqrt{(331,1468)^{2}+(84,99300149)^{2}}$

$=341,88 \mathrm{~N}$.

Karena reaksi maksimum terjadi pada bantalan D, maka nilainya dijadikan sebagai dasar perhitungan untuk menentukan beban ekivalen dinamis.

Maka: Beban radial (Fr) $\quad=341,88 \mathrm{~N}$

$$
\begin{array}{ll}
\quad \begin{array}{l}
\text { Beban aksial }(\mathrm{Fa}) \\
\alpha=30^{\circ}(\text { sudut kontak })
\end{array} & =341,88 \tan \alpha ; \\
=197,385 \mathrm{~N} & =341,88 \tan 30^{\circ}
\end{array}
$$

\section{Umur nominal (Lh)}

$$
\begin{aligned}
\mathrm{Lh} & =500 \mathrm{Fh}^{3} \\
& =500 \times 6,828^{3}=159185,3(\mathrm{~h})
\end{aligned}
$$

Dengan keandalan 95(\%), $a_{1}=0,62$ ( table sularso,hal 137),

Maka: $\mathrm{L}_{5}=159185,3 \times 0.62=98694,9 \equiv 98695$

(h)

Sehingga: 98685 (h) > 20000(h) perancangan dapat diterima sesuai table sularso

\section{Bantalan Poros Antara}

Sesuai dengan catalog bantalan pada table sularso, direncanakan diameter dalam bantalan (d) $=25 \mathrm{~mm}$ yang mempunyai harga kapasitas nominal dinamis spesifik $(\mathrm{C})=790(\mathrm{Kg}) \mathrm{x}$ $9,80665(\mathrm{~N})=7747,254 \mathrm{~N}$, dan harga kapasitas nominal statis spesifik $(\mathrm{Co})=530(\mathrm{Kg}) \mathrm{x}$ $9,80665(\mathrm{~N})=5197,525 \mathrm{~N}$

Resultan reaksi -reaksi (lihat perencanaan poros) pada masing-masing bantalan dihitung sebagia berikut:

$\mathrm{R}_{\mathrm{A}}=\sqrt{\mathrm{R}_{\mathrm{AH}}{ }^{2}+\mathrm{R}_{\mathrm{AV}}{ }^{2}}$

$\sqrt{(439,5705)^{2}+(404,8471,)^{2}}=597,598 \mathrm{~N}$.

$\mathrm{R}_{\mathrm{C}}=\sqrt{\mathrm{R}_{\mathrm{CH}}{ }^{2}+\mathrm{R}_{\mathrm{CV}}{ }^{2}}$ $=$

$\sqrt{(92,8454)^{2}+(1113,4656)^{2}}=1117,3298 \mathrm{~N}$.

Karena reaksi maksimum terjadi pada bantalan $\mathrm{C}$, maka nilainya dijadikan sebagai dasar perhitungan untuk menentukan beban ekivalen dinamis.

Maka:

Beban radial $(\mathrm{Fr}) \quad=1117,33 \mathrm{~N}$

Beban aksial $(\mathrm{Fa}) \quad=1117,33 \tan \alpha$

$\alpha=30^{\circ}$ (sudut kontak )

$$
=1117,33 \tan 30^{\circ}=645,1 \mathrm{~N}
$$

Beban ekivalen dinamis $\operatorname{Pr}(N)$

$\mathrm{Pr}=\mathrm{X} . \mathrm{V} . \mathrm{Fr}+\mathrm{Y} . \mathrm{Fa}$

$\begin{array}{lll}\mathrm{Y}=0.56 & \mathrm{Y}=1.45 & \mathrm{~V}=1(\end{array}$

bila yang berputar cincin dalam)

Xo $=0.6 \quad$ Yo $=0.5$ 
Sehingga: $\operatorname{Pr}=0,56 \cdot 1 \cdot 1117,33+1,45 \cdot 645,1=$ $1561,1 \mathrm{~N}$

-.Beban ekivalen statis Po $(N)$

$\mathrm{Po}=\mathrm{Xo} . \mathrm{Fr}+\mathrm{Yo} \mathrm{Fa}$

$=0,6.1117,33+0,5.645,1=992,95 \mathrm{~N}$

Factor kecepatan (Fn)

$F n=\left[\frac{33,3}{n}\right]^{\frac{1}{3}}$

$F n=\left[\frac{33,3}{300}\right]^{\frac{1}{3}}=0,481$

Factor umur (fh)

$$
\begin{aligned}
F h & =F n\left[\frac{C}{P}\right] \\
& =0,481\left[\frac{7747,254}{1561,1}\right]=2,398
\end{aligned}
$$

\section{Umur nominal (Lh)}

$$
\begin{aligned}
\mathrm{Lh} & =500 \mathrm{Fh}^{3} \\
& =500 \times 2,389^{3}=6800,75(\mathrm{~h})
\end{aligned}
$$

Dengan keandalan 90(\%), a

Maka: $\mathrm{L}_{5}=6800,75 \mathrm{x} 1=6800,75 \equiv 6801(\mathrm{~h})$

Sehingga: $6801(\mathrm{~h})>5000(\mathrm{~h})$ perancangan dapat diterima sesuai table sularso hal 137.

\section{Bantalan Ulir Kempa}

Bantalan yang dipakai untuk poros ini adalah bantalan kerucut dengan pertimbangan bahwa bantalan akan dibebani beban radial dan aksial sekaligus. Besarnya beban aksial adalah 29,03N. sedangkan beban radial dihitung menurut reaksi yang terbesar dari bantalannya.reaksi-reaksi itu adalah $\mathrm{R}_{\mathrm{C}}=519,17 \mathrm{~N}$ dan $\mathrm{R}_{\mathrm{D}}=291,67 \mathrm{~N}$.

Sesuai dengan catalog bantalan pada table sularso hal 144, direncanakan diameter dalam bantalan $(\mathrm{d})=35 \mathrm{~mm}$ yang mempunyai harga kapasitas nominal dinamis spesifik $(\mathrm{C})=5350$ $(\mathrm{Kg}) \times 9,80665(\mathrm{~N})=52465,58 \mathrm{~N}$, dan harga kapasitas nominal statis spesifik $(\mathrm{Co})=3950$ $(\mathrm{Kg}) \times 9,80665(\mathrm{~N})=38736,27 \mathrm{~N}$

Beban ekivalen dinamis $\operatorname{Pr}(N)$

$\mathrm{Pr}=\mathrm{X} . \mathrm{V} . \mathrm{Fr}+\mathrm{Y} . \mathrm{Fa}$

Dimana: nilai-nilai $\mathrm{X}, \mathrm{Y}, \mathrm{V}, \mathrm{Xo}, \mathrm{Yo}$ diambil dari table 4.9, Sularso, hal 135
$\mathrm{Y}=0.56$
$\mathrm{Y}=1.45$
$\mathrm{V}=1($
bila yang berputar cincin dalam)
Xo $=0.6 \quad$ Yo $=0.5$

Sehingga: $\operatorname{Pr}=0,56 \cdot 1 \cdot 519,17+1,45 \cdot 291,67=$ 713,66 N

-.Beban ekivalen statis Po $(N)$

$$
\mathrm{Po}=\mathrm{Xo} . \mathrm{Fr}+\mathrm{Yo} \text { Fa ......Sularso, hal } 135
$$$$
=0,6.519,17+0,5.291,67=457,337 \mathrm{~N}
$$

-.Factor kecepatan (Fn)

$$
F n=\left[\frac{33,3}{n}\right]^{3 / 10}
$$

dimana:

$(\mathrm{n})=54 \mathrm{rpm}$ (putaran poros kempa)

$F n=\left[\frac{33,3}{54}\right]^{3 / 10}=0,1996$

-.Factor umur (fh)

$$
\begin{aligned}
& F h=F n\left[\frac{C}{P}\right] \ldots \ldots \ldots \ldots . . . \text { Sularso, hal } 136 \\
& =0,1996\left[\frac{52465,58}{1170,997}\right]=8,94
\end{aligned}
$$

\section{-.Umur nominal (Lh)}

$$
\begin{aligned}
\mathrm{Lh} & =500 \mathrm{Fh}^{3} \\
& =500 \times 8,94^{3}=357258,5(\mathrm{~h})
\end{aligned}
$$

Dengan keandalan 95(\%), $\mathrm{a}_{1}=0,62$ ( table sularso,hal 137),

Maka: $\mathrm{L}_{5}=357258,5 \times 0,62=221500,27 \equiv$ 2215001(h)

Sehingga: $2215001(\mathrm{~h})>20000(\mathrm{~h})$ perancangan dapat diterima sesuai table sularso

\section{KESIMPULAN}

Dari perhitungan-perhitungan yang dilakukan diperoleh kesimpulan untuk merencanakan mesin pembuat bahan baku pati dari ubi kayu adalah berdasarkan ukuran - ukuran sebagai berikut:

Penentapan kapasitas (kapasitas yang direncanakan adalah $30 \mathrm{~kg} / \mathrm{jam}$ )

Penentuan daya dan putaran motor

Putaran rotor pemarut $\quad=446 \mathrm{rpm}$

Putaran ulir kempa $\quad=54 \mathrm{rpm}$

Daya pemarutan $\quad=412,31 \mathrm{Watt}$

Daya dan pengempaan $=57,67 \mathrm{Watt}$

Pemilihan Sabuk dan Pulli

Sabuk $1=$ nomor 74 dengan panjang $1880 \mathrm{~mm}, 1$ buah

Sabuk $2=$ nomor 78 dengan panjang $1981 \mathrm{~mm}, 1$ buah 
Sabuk 3 = nomor 95 dengan panjang $2413 \mathrm{~mm}, 1$ buah

Perencanaan Poros

Bahan poros, baja karbon (JIS G 4501) S30C yang mempunyai tegangan tarik $48 \mathrm{~kg} / \mathrm{mm} 2 \mathrm{x}$ $9,80665=568,78 \mathrm{~N} / \mathrm{mm} 2, \mathrm{Sf} 1=60$ untuk bahan $\mathrm{SC}, \mathrm{Sf} 2=1,3-3,0$ (dalam perancangan diambil $\mathrm{Sf} 2=2$ )

\section{Poros Pemarut.}

Torsi pada poros $(\mathrm{T}) \quad=32116,65 \mathrm{~N} / \mathrm{mm}$ Diameter poros $(\mathrm{d}) \quad=\quad 22 \mathrm{~mm}$ Diameter rotor pemarut $=120 \mathrm{~mm}$ Panjang kawat pemarut $=5 \mathrm{~mm}$ Diameter kawat pemarut $=\quad 1,5 \mathrm{~mm}$ Tegangan ijin bengkok $(\sigma) \quad=102,28 \mathrm{~N} / \mathrm{mm}^{2}$ Tegangan geser ijin ()$=\quad 51,19 \mathrm{~N} / \mathrm{mm}^{2}$

Diameter poros $(\mathrm{d})=24 \mathrm{~mm}$

Tegangan ijin bengkok $(\sigma)=102,28 \mathrm{~N} / \mathrm{mm}^{2}$

Tegangan geser ijin ()$=51,19 \mathrm{~N} / \mathrm{mm}^{2}$

Poros kempa

Torsi pada poros $(\mathrm{T})=179049,3 \mathrm{~N} / \mathrm{mm}$

Diameter poros $(\mathrm{d}) \quad=35 \mathrm{~mm}$

Tegangan ijin bengkok $(\sigma)=102,28 \mathrm{~N} / \mathrm{mm} 2$

Tegangan geser ijin ()$=51,19 \mathrm{~N} / \mathrm{mm} 2$

Pemilihan kopling

Kopling yang dipilih adalah kopling rantai yang digunakan pada poros panyambungan antara poros reduser dengan poros ulir kempa.

Pemilihan pegas

Diameter kawat pegas $=3,5 \mathrm{~mm}$. tegangan geser ijin ()$=229,5 \mathrm{~N} / \mathrm{mm} 2$

Tegangan yang tejadi ()$=59,96 \mathrm{~N} / \mathrm{mm} 2$

Pemilihan baut pada rotor pemarut

Baut yang digunakan untuk mengikat rotor pemarut sebanyak enam (6) buah, Menggunakan baja karbon dengan kadar karbon 0,2-0,3 mempuyai tegangan tarik ijin $4,8 \mathrm{~kg} / \mathrm{mm} 2 \mathrm{x}$ $9,80665=47 \mathrm{~N} / \mathrm{mm} 2$

Pemilahan Bantalan
Bantalan Rotor Pemarut

Diameter dalam Bantalan $=25 \mathrm{~mm}$

Harga Kapasitas Nominal Spesifik $(C)=470 \mathrm{~kg}$

Harga Kapasitas Spesifik (Co) $=296 \mathrm{Kg}$

Bantalan Poros Antara

-.Diameter dalam Bantalan $=25 \mathrm{~mm}$

-.Harga Kapasitas Nominal Spesifik(C) $=790 \mathrm{Kg}$

-.Harga Kapasitas Spesifik (Co) $=530 \mathrm{Kg}$

Bantalan Ulir Kempa

-.Diameter dalam Bantalan $=35 \mathrm{~mm}$

-.Harga Kapasitas Nominal Spesifik(C) $=5350 \mathrm{Kg}$

-.Harga Kapasitas Spesifik $(\mathrm{Co})=3950 \mathrm{Kg}$

\section{DAFTAR PUSTAKA}

Arianto dan Jamasri, Proses Stretching Pada Pruduk Pembubutan Alumunium 2024-T3 2000.

El Domity Et al, Proses Stretching Material Kekuatan Bahan, 1996.

Li dan Qiao, Pengeruh Pelapisan dan Shop Peening Terhadap Kekuatan Fatik Baja Medium, 1992.

Frea. W. Taylor Dan M. White, Teori Material Mata Pahat (High Speed Stell, 1900.

Taufiiq Rochim, Teori parameter permesinan, HEDS, 1991, Tool wear \& Roughness

Taufiiq Rochim, Teori Dan Teknologi Proses Pemotongan Logam, HEDS, 1993, Tool wear \& Roughness

Taufiiq Rochim, Teori kekasaran permukaan, HEDS, 1995, Tool wear \& Roughness

Priambodo, komposisi baja kecepatan tinggi dan elemen paduan, 1990.

http://www.matls.com/search/spesificmaterial.asp ?bassnum=MA6061T6,

Material properties: 6061-T6 alumunium

Frofessor I.S. Jawahir, Chip Flow And Chip

Control Machining Operation.Loading, Proc. Phys. Soc, London, B62, 676-700, 1949. 